\title{
ANALISIS PENERIMAAN GOOGLE CLASSROOM MENGGUNAKAN PENDEKATAN TECHNOLOGY ACCEPTANCE MODEL (TAM) DAN END-USER COMPUTING SATISFACTION (EUCS) (STUDI KASUS: UNIVERSITAS INFORMATIKA DAN BISNIS INDONESIA)
}

\author{
${ }^{1}$ Zatin Niqotaini, ${ }^{2}$ Budiman \\ Program Studi Sistem Informasi, Universitas Informatika dan Bisnis Indonesia \\ Jl. Soekarno Hatta No. 643 Bandung \\ zatinniqotaini@gmail.com, budiman1982@gmail.com
}

\begin{abstract}
ABSTRAK
Pandemi virus corona (COVID-19) memberikan dampak besar terhadap berbagai aktivitas manusia di seluruh dunia khususnya negara Indonesia, salah satunya aktivitas pendidikan dan kegiatan pembelajaran di kampus. Kebijakan dari pemerintah tentang WFH (work from home) menjadikan proses kegiatan pembelajaran secara tatap muka di kampus dihentikan sementara sejak bulan Maret 2020 hingga waktu yang belum dapat ditentukan. Universitas Informatika dan Bisnis Indonesia sebagai salah satu institusi pendidikan swasta di Jawa Barat, dituntut untuk mengikuti perubahan metode pembelajaran yaitu pembelajaran jarak jauh (online) yang sebelumnya menggunakan tatap muka secara langsung. Salah satu platform yang banyak digunakan adalah google classroom. Google classroom merupakan aplikasi yang memungkinkan terbentuknya kelas di dunia maya, sebagai salah satu platform yang banyak digunakan tentunya perlu diperlukan evaluasi kepuasaan pengguna terutama mahasiswa agar terdapat perbaikan kedepannya. Penelitian ini dikaji dengan menggunakan model Technology Acceptance Model (TAM) dengan mempertimbangkan faktor Persepsi Kegunaan (Perceived Usefulness), Persepsi Kemudahan Penggunaan (Perceived Ease Of Use) dan Sikap Terhadap Perilaku (Attitude Toward Using). End-User Computing Satisfaction (EUCS) dengan mempertimbangkan Isi (Content), Akurasi (Accuracy), Tampilan (Format), Kemudahan (Ease) dan Ketepatan Waktu (Timeliness). Subyek penelitian yang digunakan adalah mahasiswa di lingkungan Unibi. Hipotesis yang menghasilkan hubungan antar konstruk di dalam TAM dan EUCS diukur dengan Structural Equation Model (SEM) dan software AMOS 26. Hasil penelitian ini menunjukkan bahwa model TAM dan EUCS dapat menjelaskan faktor - faktor yang mempengaruhi penerimaan google classroom pada Unibi dimana Perceived Usefullness (PU) dipengaruhi oleh Perceived Ease of Use (PEOU) 52,2\%. Attitude Toward Using (AT) dipengaruhi oleh Perceived Usefullness (PU) 34,4\%, Content (CT) 25,4\%, Accuracy (AC) 11,9\%, dan Format (FT) 18,4\%.
\end{abstract}

Kata kunci : E-learning, Google Classroom, Technology Acceptance Model (TAM), End User Computing Satisfaction (EUCS).

\section{PENDAhuluan}

Pembelajaran daring merupakan sistem pembelajaran yang dilakukan dengan tidak bertatap muka langsung, tetapi menggunakan platform yang dapat membantu proses belajar mengajar yang dilakukan meskipun jarak jauh. Tujuan dari adanya pembelajaran daring ialah memberikan layanan pembelajaran bermutu dalam jaringan yang bersifat masif dan terbuka untuk menjangkau peminat ruang belajar agar lebih banyak dan lebih luas (Sofyana \& Abdul, 2019)[1]. Dosen dan mahasiswa juga bisa berkomunikasi secara interaktif melalui pembelajaran tersebut yang difasilitasi dengan komputer, internet atau smartphone.
Sebagai upaya untuk mendukung proses pembelajaran secara online, serta meningkatkan mutu pembelajaran, Universitas Informatika dan Bisnis Indonesia berupaya memberikan hasil yang terbaik terutama penggunaan teknologi baru. Salah satu cara dalam pelaksanaan proses pembelajaran secara online dengan menggunakan Google Classroom. Google Classroom adalah layanan berbasis internet yang disediakan oleh Google sebagai sebuah sistem e-learning. Service ini didesain untuk membantu pengajar membuat dan membagikan tugas kepada pelajar secara paperless (Hakim, 2016) [2]. Pada prosesnya ditemukan beberapa masalah pengguna terutama mahasiswa yang merasa kesulitan dalam mengoperasikan platform ini, sehingga 
memunculkan konflik dan perbedaan pendapat mengenai platform e-learning manakah yang lebih mudah dan lebih baik untuk digunakan.

Penerapan teknologi baru dalam suatu organisasi bukanlah hal yang mudah diterapkan karena penerapan teknologi baru akan berpengaruh pada keseluruhan organisasi, terutama sumber daya manusia. Faktor pengguna sangat penting diperhatikan dalam penerapan sistem yang baru, karena tingkat kesiapan pengguna untuk menerima sistem yang baru memiliki pengaruh besar dalam menentukan sukses tidaknya penerapan sistem tersebut. Dari permasalahan di atas maka dibutuhkan suatu metode yang mampu menganalisis, mengukur dan menggali sejauh mana penerimaan sistem informasi penting dalam organisasi atau perusahaan.

Tingkat penerimaan pengguna terhadap penerapan penggunaan Google Classroom di Universitas Informatika dan Bisnis Indonesia dapat diukur dengan pendekatan teori yang dapat menggambarkan tingkat penerimaan dan penggunaan terhadap suatu teknologi yaitu teori gabungan Technology Acceptance Model (TAM) dan End-User Computing Satisfaction (EUCS). Melalui teori gabungan TAM dan EUCS, dapat dipahami bahwa reaksi dan persepsi pengguna terhadap teknologi dapat mempengaruhi sikapnya dalam penerimaan penggunaan teknologi.

Penelitian TAM dan EUCS pernah dilakukan oleh beberapa peneliti antara lain Evi Yulianingsih pada tahun 2016 [3] menggunakan TAM dan EUSC untuk menganalisis penerimaan penerapan e-learning dibeberapa Perguruan Tinggi Kota Palembang. Khairun Nisa \& Ilhamsyah pada tahun 2020 [4] menggunakan TAM dan EUCS untuk menganalisis penerimaan Siakad di Universitas Tanjungpura. Anthony Eko Hadisuwarno \& Rahadian Bisma pada tahun 2020 [5] menggunakan TAM dan EUCS untuk menganalisis penerimaan pengguna terhadap aplikasi e-Kinerja pada kepolisian.

Penerapan sistem ditentukan oleh faktorfaktor yang mempengaruhi penerimaan pengguna atas teknologi informasi. Dirasakan juga oleh Universitas Informatika dan Bisnis Indonesia harus melakukan pengukuran atas keberhasilan implementasi platform google scholar untuk mendukung proses pembelajaran secara online, serta meningkatkan mutu pembelajaran. Disisi lain Universitas Informatika dan Bisnis Indonesia juga harus mempertimbangkan aspek manusia yang sangat penting disamping aspek teknologi.

Berdasarkan uraian latar belakang masalah di atas, maka peneliti bermaksud untuk melakukan penelitian dengan menganalisa atau mengidentifikasi faktor-faktor apa saja yang mempengaruhi perilaku pengguna. Berjudul "Analisis Penerimaan Google Classroom Menggunakan Pendekatan Technology Acceptance Model (TAM) Dan End-User Computing Satisfaction (EUCS) (Studi Kasus: Universitas Informatika Dan Bisnis Indonesia)".

\section{METODE PENELITIAN}

Penelitian ini akan dilakukan untuk menganalisa bagaimana penerimaan Google Clasroom dengan menggunakan Model TAM dan EUCS. Target penelitian dalam penelitian ini adalah mahasiswa Unibi. Pengumpulan data yang dibutuhkan dalam penelitian ini adalah menggunakan data primer dengan kuisioner secara online.

A. Tahapan Penelitian

Adapun tahapan penelitian tentang penerimaan Google Classroom dapat dilihat pada gambar 1:

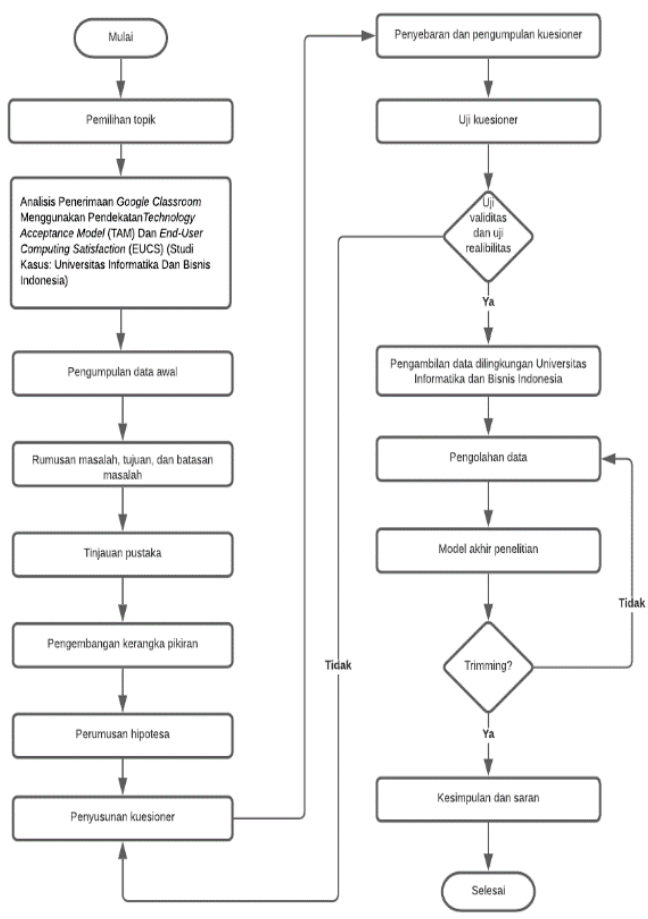

Gambar 1. Tahapan Penelitian 


\section{B. Pengumpulan Data}

Pada tahap awal, penyebaran kuesioner pada penelitian kali ini diberikan langsung kepada para responden yaitu para mahasiswa di Universitas Informatika dan Bisnis Indonesia dimulai tanggal 01 sampai dengan 25 Maret 2021. Kuesioner yang ada terlebih dahulu diuji coba sebanyak dua kali dengan jumlah responden terbatas sebanyak 30 orang. Tujuannya adalah untuk melakukan uji validitas dan uji reliabilitas atas kuesioner tersebut. Setelah melakukan pengujian validitas dan reliabilitas, model penelitian akan di trimming sesuai dengan hasil pengujian untuk menghasilkan model yang lebih sederhana. Setelah itu kuesioner dari model yang telah di trimming akan kembali disebar kepada responden pada Unibi.

Skala pengukuran yang digunakan dalam kuesioner penelitian ini adalah skala likert dan skala sematic deferential. Kedua skala ini digunakan agar responden lebih mudah dalam menjawab pertanyaan kuesioner tersebut. Skala sematic deferential yang digunakan berbentuk checklist yang tersusun urut dalam satu garis mulai dari "sangat setuju" yang terletak pada sisi kanan sampai "sangat tidak setuju" pada sisi kiri. Kuesioner menggunakan google form yang dapat diakses oleh mahasiswa Unibi.

\section{Pembuatan Kuesioner}

Pembuatan pertanyaan dalam kuesioner yang digunakan di penelitian ini mengacu pada konstruk yang digunakan dalam peneltian. Selain itu pertanyaan yang digunakan juga mengacu kepada indikator yang digunakan oleh peneliti terdahulu dalam mengukur kesiapan dan penerimaan teknologi. Variabel penelitian yang digunakan sebagai acuan kuesioner adalah Perceived Usefullness, Perceived Ease of Use, Attitude Toward Using Technology, Content, Accuracy, Format, Timeliness, Ease. Tabel 1 merinci pertanyaan yang akan digunakan dalam kuesioner pada penelitian ini.

Tabel 1. Konstruk dan Pertanyaan Kuesioner Penelitian

\begin{tabular}{|l|l|l|l|l|l|}
\hline Konstruk & Indikator & $\begin{array}{l}\text { Ko } \\
\text { de }\end{array}$ & No & Kuesioner & $\begin{array}{l}\text { Skal } \\
\text { a }\end{array}$ \\
\hline
\end{tabular}

\begin{tabular}{|l|l|l|l|l|l|}
\hline $\begin{array}{l}\text { Perceived } \\
\text { Usefullness } \\
\text { (Persepsi } \\
\text { Kegunaan) }\end{array}$ & Bekerja & PU & 1 & $\begin{array}{l}\text { Menurut } \\
\text { Saya, } \\
\text { lebih cepat } \\
\text { Classroom } \\
\text { bermanfaat } \\
\text { dalam } \\
\text { menunjang } \\
\text { perkuliahan } \\
\text { ? }\end{array}$ & Skal \\
likert \\
\hline
\end{tabular}




\begin{tabular}{|c|c|c|c|c|c|}
\hline & $\begin{array}{l}\text { Mudah } \\
\text { mendapatka } \\
\mathrm{n} \text { informasi }\end{array}$ & $\begin{array}{l}\mathrm{PE} \\
\mathrm{O} \\
\mathrm{U} \\
2\end{array}$ & 8 & $\begin{array}{l}\text { Google } \\
\text { Classroom } \\
\text { mudah } \\
\text { dioperasika } \\
\mathrm{n} ?\end{array}$ & \\
\hline & $\begin{array}{l}\text { Interaksi } \\
\text { cukup jelas } \\
\text { dan mudah } \\
\text { dipahami }\end{array}$ & $\begin{array}{l}\mathrm{PE} \\
\mathrm{O} \\
\mathrm{U} \\
3\end{array}$ & 9 & $\begin{array}{l}\text { Google } \\
\text { Classroom } \\
\text { mudah } \\
\text { diakses } \\
\text { untuk } \\
\text { digunakan? }\end{array}$ & \\
\hline & $\begin{array}{l}\text { Interaksi } \\
\text { fleksibel }\end{array}$ & $\begin{array}{l}\mathrm{PE} \\
\mathrm{O} \\
\mathrm{U} \\
4\end{array}$ & 10 & $\begin{array}{l}\text { Tampilan } \\
\text { Google } \\
\text { Classroom } \\
\text { sangat jelas } \\
\text { dan mudah } \\
\text { dipahami? }\end{array}$ & \\
\hline & $\begin{array}{l}\text { Mudah } \\
\text { untuk } \\
\text { menjadi } \\
\text { mahir }\end{array}$ & $\begin{array}{l}\mathrm{PE} \\
\mathrm{O} \\
\mathrm{U} \\
5\end{array}$ & 11 & $\begin{array}{l}\text { Google } \\
\text { Classroom } \\
\text { fleksibel } \\
\text { digunakan, } \\
\text { bisa diakses } \\
\text { kapan saja } \\
\text { dan dimana } \\
\text { saja? }\end{array}$ & \\
\hline & $\begin{array}{l}\text { Mudah } \\
\text { dimanfaatk } \\
\text { an }\end{array}$ & $\begin{array}{l}\mathrm{PE} \\
\mathrm{O} \\
\mathrm{U} \\
6\end{array}$ & 12 & $\begin{array}{l}\text { Menurut } \\
\text { saya, sangat } \\
\text { mudah } \\
\text { untuk mahir } \\
\text { menggunak } \\
\text { an Google } \\
\text { Classroom? }\end{array}$ & \\
\hline \multirow[t]{4}{*}{$\begin{array}{l}\text { Attitude } \\
\text { Toward } \\
\text { Using } \\
\text { Technology } \\
\text { (Sikap } \\
\text { terhadap } \\
\text { perilaku) }\end{array}$} & $\begin{array}{l}\text { Senang } \\
\text { menggunak } \\
\text { an } \\
\text { teknologi }\end{array}$ & $\begin{array}{l}\mathrm{A} \\
\mathrm{T} \\
1\end{array}$ & 13 & $\begin{array}{l}\text { Saya } \\
\text { merasa } \\
\text { puas } \\
\text { menggunak } \\
\text { an Google } \\
\text { Classroom? }\end{array}$ & $\begin{array}{l}\text { Skal } \\
\mathrm{a} \\
\text { likert }\end{array}$ \\
\hline & $\begin{array}{l}\text { Memberika } \\
\mathrm{n} \\
\text { kesenangan }\end{array}$ & $\begin{array}{l}\mathrm{A} \\
\mathrm{T} \\
2\end{array}$ & 14 & $\begin{array}{l}\text { Saya } \\
\text { percaya } \\
\text { penggunaan } \\
\text { Google } \\
\text { Classroom } \\
\text { akan } \\
\text { semakin } \\
\text { sering } \\
\text { digunakan } \\
\text { dimasa } \\
\text { depan? }\end{array}$ & \\
\hline & Antusias & $\begin{array}{l}\mathrm{A} \\
\mathrm{T} \\
3\end{array}$ & 15 & $\begin{array}{l}\text { Menurut } \\
\text { Saya, } \\
\text { tampilan } \\
\text { antar muka } \\
\text { yang } \\
\text { terdapat di } \\
\text { Google } \\
\text { Classroom } \\
\text { tidak } \\
\text { membosank } \\
\text { an untuk } \\
\text { digunakan? }\end{array}$ & \\
\hline & $\begin{array}{l}\text { Tidak } \\
\text { pernah } \\
\text { bosan }\end{array}$ & $\begin{array}{l}\mathrm{A} \\
\mathrm{T} \\
4\end{array}$ & 16 & $\begin{array}{l}\text { Saya } \\
\text { senang } \\
\text { menggunak } \\
\text { an Google } \\
\text { Classroom? }\end{array}$ & \\
\hline $\begin{array}{l}\text { Content } \\
\text { (Isi) }\end{array}$ & $\begin{array}{l}\text { Informasi } \\
\text { tepat }\end{array}$ & $\begin{array}{l}\mathrm{CT} \\
1\end{array}$ & 17 & $\begin{array}{l}\text { Google } \\
\text { Classroom } \\
\text { menyediaka } \\
\mathrm{n} \text { informasi } \\
\text { yang Saya }\end{array}$ & $\begin{array}{l}\text { Skal } \\
\mathrm{a} \\
\text { likert }\end{array}$ \\
\hline
\end{tabular}

\begin{tabular}{|c|c|c|c|c|c|}
\hline & & & & $\begin{array}{l}\text { butuhkan } \\
\text { secara } \\
\text { akurat } \\
\text { selama } \\
\text { kegiatan } \\
\text { perkuliahan } \\
\text { ? }\end{array}$ & \\
\hline & $\begin{array}{l}\text { Isi } \\
\text { informasi } \\
\text { memenuhi }\end{array}$ & $\begin{array}{l}\text { CT } \\
2\end{array}$ & 18 & $\begin{array}{l}\text { Informasi } \\
\text { yang } \\
\text { dihasilkan } \\
\text { oleh Google } \\
\text { Classroom } \\
\text { membantu } \\
\text { anda dalam } \\
\text { kegiatan } \\
\text { perkuliahan } \\
\text { ? }\end{array}$ & \\
\hline & $\begin{array}{l}\text { Laporan } \\
\text { sesuai } \\
\text { kebutuhan }\end{array}$ & $\begin{array}{l}\text { CT } \\
3\end{array}$ & 19 & $\begin{array}{l}\text { Menurut } \\
\text { Saya, } \\
\text { Google } \\
\text { Classroom } \\
\text { menyediaka } \\
\text { n bahan } \\
\text { materi } \\
\text { maupun } \\
\text { tugas sesuai } \\
\text { dengan } \\
\text { kebutuhan } \\
\text { perkuliahan } \\
\text { ? }\end{array}$ & \\
\hline & $\begin{array}{l}\text { Informasi } \\
\text { yang cukup }\end{array}$ & $\begin{array}{l}\text { CT } \\
4\end{array}$ & 20 & $\begin{array}{l}\text { Google } \\
\text { Classroom } \\
\text { menyediaka } \\
\mathrm{n} \text { informasi } \\
\text { secara } \\
\text { memadai? }\end{array}$ & \\
\hline & $\begin{array}{l}\text { Adanya } \\
\text { waktu dan } \\
\text { tanggal } \\
\text { akses } \\
\text { website }\end{array}$ & $\begin{array}{l}\mathrm{CT} \\
5\end{array}$ & 21 & $\begin{array}{l}\text { Dalam } \\
\text { menggunak } \\
\text { an Google } \\
\text { Classroom } \\
\text { terdapat } \\
\text { waktu dan } \\
\text { tanggal } \\
\text { akses } \\
\text { website } \\
\text { setiap user } \\
\text { (pengguna) } \\
\text { ? }\end{array}$ & \\
\hline \multirow[t]{3}{*}{$\begin{array}{l}\text { Accuracy } \\
\text { (Keakuatan } \\
\text { ) }\end{array}$} & $\begin{array}{l}\text { Informasi } \\
\text { yang } \\
\text { dihasilkan } \\
\text { akurat }\end{array}$ & $\begin{array}{l}\mathrm{A} \\
\mathrm{C} \\
1\end{array}$ & 22 & $\begin{array}{l}\text { Menurut } \\
\text { Saya, } \\
\text { Google } \\
\text { Classroom } \\
\text { memberika } \\
\mathrm{n} \quad \text { hasil } \\
\text { informasi } \\
\text { yang } \\
\text { akurat? }\end{array}$ & $\begin{array}{l}\text { Skal } \\
\text { a } \\
\text { likert }\end{array}$ \\
\hline & $\begin{array}{l}\text { Puas } \\
\text { dengan } \\
\text { akurasi } \\
\text { sistem }\end{array}$ & $\begin{array}{l}\mathrm{A} \\
\mathrm{C} \\
2\end{array}$ & 23 & $\begin{array}{l}\text { Keakuratan } \\
\text { Google } \\
\text { Classroom } \\
\text { memberika } \\
\text { n kepuasan } \\
\text { untuk } \\
\text { Saya? }\end{array}$ & \\
\hline & $\begin{array}{l}\text { Jarang } \\
\text { terjadi } \\
\text { error pada } \\
\text { sistem }\end{array}$ & $\begin{array}{l}\mathrm{A} \\
\mathrm{C} \\
3\end{array}$ & 24 & $\begin{array}{l}\text { Menurut } \\
\text { saya, jarang } \\
\text { terjadinya } \\
\text { error saat } \\
\text { menggunak } \\
\text { an Google } \\
\text { Classroom? }\end{array}$ & \\
\hline
\end{tabular}




\begin{tabular}{|c|c|c|c|c|c|}
\hline & $\begin{array}{l}\text { Adanya } \\
\text { user id dan } \\
\text { password } \\
\text { untuk } \\
\text { setiap user }\end{array}$ & $\begin{array}{l}\text { A } \\
\text { C } \\
4\end{array}$ & 25 & $\begin{array}{l}\text { Adakah } \\
\text { user id dan } \\
\text { password } \\
\text { saat } \\
\text { menggunak } \\
\text { an Google } \\
\text { Classroom? }\end{array}$ & \\
\hline & $\begin{array}{l}\text { Adanya } \\
\text { keterangan } \\
\text { tahapan dan } \\
\text { waktu } \\
\text { proses }\end{array}$ & $\begin{array}{l}\text { A } \\
\text { C } \\
5\end{array}$ & 26 & $\begin{array}{l}\text { Adakah } \\
\text { keterangan } \\
\text { tahapan dan } \\
\text { waktu } \\
\text { proses di } \\
\text { dalam } \\
\text { Google } \\
\text { Classroom? }\end{array}$ & \\
\hline \multirow[t]{5}{*}{$\begin{array}{l}\text { Format } \\
\text { (Tampilan) }\end{array}$} & $\begin{array}{l}\text { Penyajian } \\
\text { output/lapo } \\
\text { ran }\end{array}$ & $\begin{array}{l}\text { FT } \\
1\end{array}$ & 27 & $\begin{array}{l}\text { Output } \\
\text { (hasil akhir) } \\
\text { yang } \\
\text { ditampilkan } \\
\text { pada } \\
\text { Google } \\
\text { Classroom } \\
\text { sangat } \\
\text { berguna } \\
\text { untuk } \\
\text { Saya? }\end{array}$ & $\begin{array}{l}\text { Skal } \\
\mathrm{a} \\
\text { likert }\end{array}$ \\
\hline & $\begin{array}{l}\text { Informasi } \\
\text { jelas }\end{array}$ & $\begin{array}{l}\text { FT } \\
2\end{array}$ & 28 & $\begin{array}{l}\text { Informasi } \\
\text { yang ada di } \\
\text { Google } \\
\text { Classroom } \\
\text { menurut } \\
\text { Saya sangat } \\
\text { jelas? }\end{array}$ & \\
\hline & $\begin{array}{l}\text { Konsistensi } \\
\text { layout (tiap } \\
\text { tahapan) }\end{array}$ & $\begin{array}{l}\text { FT } \\
3\end{array}$ & 29 & $\begin{array}{l}\text { Menurut } \\
\text { saya, } \\
\text { Google } \\
\text { Classroom } \\
\text { memiliki } \\
\text { tampilan } \\
\text { ukuran } \\
\text { huruf yang } \\
\text { normal } \\
\text { (jelas dan } \\
\text { terbaca)? }\end{array}$ & \\
\hline & $\begin{array}{l}\text { Adanya } \\
\text { struktur } \\
\text { menu }\end{array}$ & $\begin{array}{l}\text { FT } \\
4\end{array}$ & 30 & $\begin{array}{l}\text { Menurut } \\
\text { saya, } \\
\text { struktur } \\
\text { menu yang } \\
\text { dimiliki } \\
\text { Google } \\
\text { Classroom } \\
\text { sangat } \\
\text { teratur? }\end{array}$ & \\
\hline & $\begin{array}{l}\text { Ukuran } \\
\text { huruf } \\
\text { normal } \\
\text { (jelas dna } \\
\text { terbaca) }\end{array}$ & $\begin{array}{l}\text { FT } \\
5\end{array}$ & 31 & $\begin{array}{l}\text { Menurut } \\
\text { saya, } \\
\text { Google } \\
\text { Classroom } \\
\text { memiliki } \\
\text { konsistensi } \\
\text { layout (tiap } \\
\text { tahapan) } \\
\text { sehingga } \\
\text { menguntun } \\
\text { gkan bagi } \\
\text { saya? }\end{array}$ & \\
\hline $\begin{array}{l}\text { Ease } \\
\text { (Kemudaha } \\
\text { n) }\end{array}$ & $\begin{array}{l}\text { User } \\
\text { friendly }\end{array}$ & $\begin{array}{l}\mathrm{E} \\
\mathrm{U} \\
1\end{array}$ & 32 & $\begin{array}{l}\text { Menurut } \\
\text { Saya, } \\
\text { Google } \\
\text { Classroom } \\
\text { bersifat } \\
\text { user } \\
\text { friendly/ra }\end{array}$ & $\begin{array}{l}\text { Skal } \\
\mathrm{a} \\
\text { likert }\end{array}$ \\
\hline
\end{tabular}

\begin{tabular}{|c|c|c|c|c|c|}
\hline & & & & $\begin{array}{l}\text { mah } \\
\text { pengguna? }\end{array}$ & \\
\hline & $\begin{array}{l}\text { Mudah } \\
\text { dioperasika } \\
\mathrm{n}\end{array}$ & $\begin{array}{l}\mathrm{E} \\
\mathrm{U} \\
2\end{array}$ & 33 & $\begin{array}{l}\text { Menurut } \\
\text { Saya, } \\
\text { menggunak } \\
\text { an Google } \\
\text { Classroom } \\
\text { mudah } \\
\text { untuk } \\
\text { digunakan? }\end{array}$ & \\
\hline & $\begin{array}{l}\text { Mudah } \\
\text { dalam } \\
\text { mendownlo } \\
\text { ad }\end{array}$ & $\begin{array}{l}\mathrm{E} \\
\mathrm{U} \\
3\end{array}$ & 34 & $\begin{array}{l}\text { Menurut } \\
\text { Saya, } \\
\text { Google } \\
\text { Classroom } \\
\text { mudah } \\
\text { digunakan } \\
\text { saat } \\
\text { mengunduh } \\
\text { bahan } \\
\text { materi } \\
\text { maupun } \\
\text { tugas } \\
\text { perkuliahan } \\
\text { ?? }\end{array}$ & \\
\hline & $\begin{array}{l}\text { Mudah } \\
\text { dalam } \\
\text { mencari } \\
\text { informasi } \\
\text { yang } \\
\text { dibutuhkan }\end{array}$ & $\begin{array}{l}\text { E } \\
U \\
4\end{array}$ & 35 & $\begin{array}{l}\text { Google } \\
\text { Classroom } \\
\text { mudah } \\
\text { dalam } \\
\text { mencari } \\
\text { informasi } \\
\text { yang } \\
\text { dibutuhkan } \\
?\end{array}$ & \\
\hline & $\begin{array}{l}\text { Mudah } \\
\text { dalam } \\
\text { menerima } \\
\text { pemberitah } \\
\text { uan }\end{array}$ & $\begin{array}{l}\mathrm{E} \\
\mathrm{U} \\
5\end{array}$ & 36 & $\begin{array}{l}\text { Google } \\
\text { Classroom } \\
\text { menarik } \\
\text { perhatian } \\
\text { mahasiswa } \\
\text { dalam } \\
\text { pembelajar } \\
\text { an? }\end{array}$ & \\
\hline \multirow[t]{3}{*}{$\begin{array}{l}\text { Timeliness } \\
\text { (Ketepatan } \\
\text { waktu) }\end{array}$} & $\begin{array}{l}\text { Tepat } \\
\text { waktu }\end{array}$ & $\begin{array}{l}\text { TL } \\
1\end{array}$ & 37 & $\begin{array}{l}\text { Menurut } \\
\text { Saya, } \\
\text { Google } \\
\text { Classroom } \\
\text { memberika } \\
\mathrm{n} \text { informasi } \\
\text { yang Saya } \\
\text { perlukan } \\
\text { dengan } \\
\text { tepat dan } \\
\text { cepat? }\end{array}$ & $\begin{array}{l}\text { Skal } \\
\mathrm{a} \\
\text { likert }\end{array}$ \\
\hline & $\begin{array}{l}\text { Informasi } \\
\text { up-to-date }\end{array}$ & $\begin{array}{l}\text { TL } \\
2\end{array}$ & 38 & $\begin{array}{l}\text { Google } \\
\text { Classroom } \\
\text { memberikan } \\
\text { informasi } \\
\text { terkini (up- } \\
\text { to-date) } \\
\text { untuk } \\
\text { Saya? }\end{array}$ & \\
\hline & $\begin{array}{l}\text { Cepat } \\
\text { dalam } \\
\text { mendownlo } \\
\text { ad } \\
\text { dokumen }\end{array}$ & $\begin{array}{l}\text { TL } \\
3\end{array}$ & 39 & $\begin{array}{l}\text { Menurut } \\
\text { Saya, } \\
\text { Google } \\
\text { Classroom } \\
\text { mudah } \\
\text { digunakan } \\
\text { saat } \\
\text { mengunduh } \\
\text { bahan } \\
\text { materi }\end{array}$ & \\
\hline
\end{tabular}




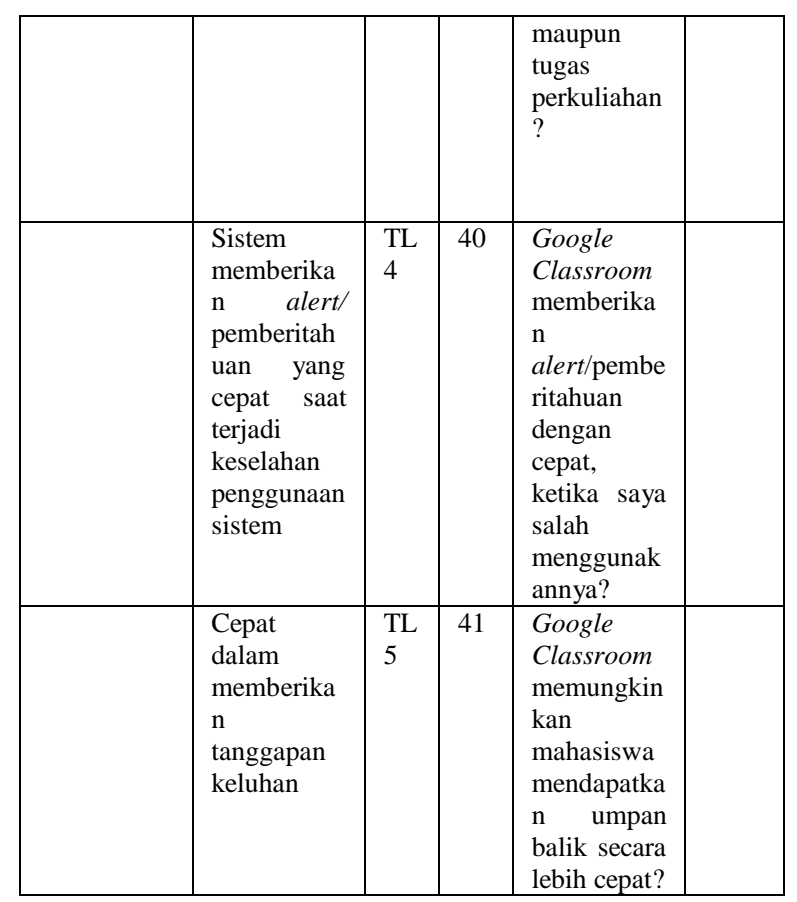

Adapun skala likert yang digunakan dalam penelitian seperti dirinci pada tabel 2 sebagai berikut:

Tabel 2 Skala likert

\begin{tabular}{|c|c|c|c|}
\hline Skala & Jawaban & Deskripsi & Keterangan \\
\hline 1 & STS & $\begin{array}{l}\text { Sangat } \\
\text { Tidak } \\
\text { Setuju }\end{array}$ & $\begin{array}{l}\text { Jawaban jika responden } \\
\text { Sangat Tidak Setuju (STS) } \\
\text { dengan pertanyaan yang } \\
\text { tertulis berdasarkan } \\
\text { pendapat dari responden } \\
\text { atau keadaan yang terjadi }\end{array}$ \\
\hline 2 & TS & $\begin{array}{l}\text { Tidak } \\
\text { Setuju }\end{array}$ & $\begin{array}{l}\text { Jawaban jika responden } \\
\text { Tidak Setuju (TS) dengan } \\
\text { pertanyaan yang tertulis } \\
\text { berdasarkan pendapat dari } \\
\text { responden atau keadaan } \\
\text { yang terjadi }\end{array}$ \\
\hline 3 & $\mathrm{~N}$ & Netral & $\begin{array}{l}\text { Jawaban jika responden } \\
\text { Netral }(\mathrm{N}) \text { dengan } \\
\text { pertanyaan yang tertulis } \\
\text { berdasarkan pendapat dari } \\
\text { responden atau keadaan } \\
\text { yang terjadi }\end{array}$ \\
\hline 4 & $\mathrm{~S}$ & Setuju & $\begin{array}{l}\text { Jawaban jika responden } \\
\text { Setuju (S) dengan } \\
\text { pertanyaan yang tertulis } \\
\text { berdasarkan pendapat dari } \\
\text { responden atau keadaan } \\
\text { yang terjadi }\end{array}$ \\
\hline 5 & SS & $\begin{array}{l}\text { Sangat } \\
\text { Setuju }\end{array}$ & $\begin{array}{l}\text { Jawaban jika responden } \\
\text { Sangat Setuju (SS) dengan } \\
\text { pertanyaan yang tertulis } \\
\text { berdasarkan pendapat dari } \\
\text { responden atau keadaan } \\
\text { yang terjadi }\end{array}$ \\
\hline
\end{tabular}

\section{Analisis Responden}

Total responden penelitian ini adalah 373 responden yang meliputi mahasiswa di Unibi. Data profil seluruh responden dapat dilihat pada tabel 3
Tabel 3. Data Profil Responden

\begin{tabular}{|c|c|c|c|}
\hline $\begin{array}{l}\text { Data } \\
\text { Responden } \\
\text { berdasarkan }\end{array}$ & Kategori & $\begin{array}{l}\text { Jumlah } \\
\text { Responden }\end{array}$ & Presentase \\
\hline \multirow{2}{*}{$\begin{array}{l}\text { Jenis } \\
\text { Kelamin }\end{array}$} & Laki- laki & 157 mahasiswa & $42 \%$ \\
\hline & Perempuan & 216 mahasiswa & $58 \%$ \\
\hline \multirow{6}{*}{$\begin{array}{l}\text { Program } \\
\text { Studi }\end{array}$} & Akuntansi & 26 mahasiswa & $7 \%$ \\
\hline & DKV & 8 mahasiswa & $2 \%$ \\
\hline & $\begin{array}{l}\text { Ilmu } \\
\text { Komunikasi }\end{array}$ & 16 mahasiswa & $4 \%$ \\
\hline & Manajemen & 33 mahasiswa & $9 \%$ \\
\hline & $\begin{array}{l}\text { Sistem } \\
\text { Informasi }\end{array}$ & 38 mahasiswa & $10 \%$ \\
\hline & Informatika & 39 mahasiswa & $10 \%$ \\
\hline
\end{tabular}

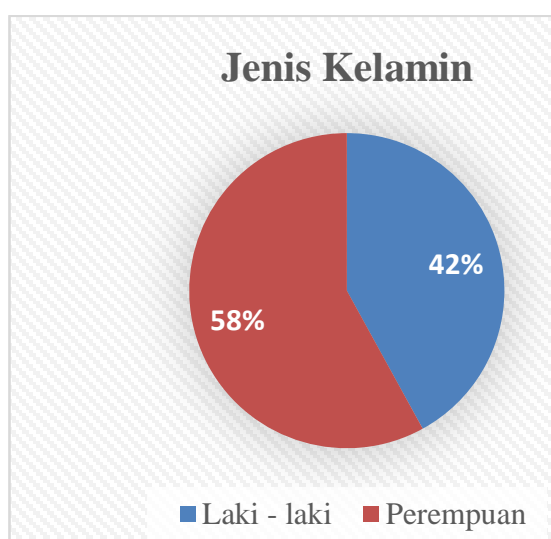

\section{Gambar 2. Diagram Profil Responden berdasarkan Jenis Kelamin}

Berdasarkan profil responden berdasarkan jenis kelamin, responden laki laki lebih sedikit dibanding responden perempuan. Responden dengan jenis kelamin laki - laki (42\%) dan jenis kelamin perempuan $(58 \%)$.

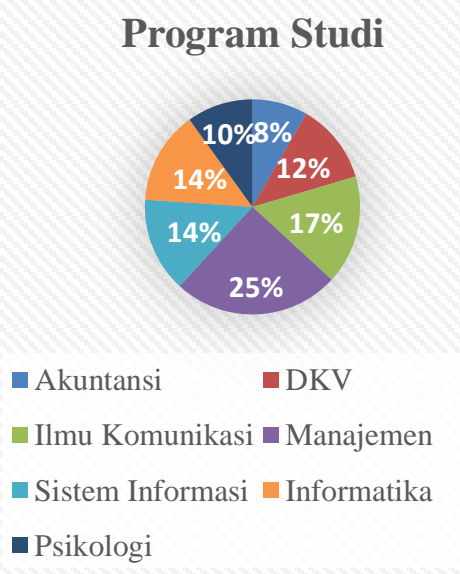

\section{Gambar 3. Diagram Profil Responden} berdasarkan Fakultas

Berdasarkan profil responden berdasarkan program studi, dengan rincian responden pada program studi akuntasi, manajemen, psikologi, DKV, informatika, system informasi dan ilmu 
komunikasi.

\section{E. Pengujian Validitas Keseluruhan}

Pada tabel 4. terdapat 41 indikator dari semua konstruk yang digunakan dapat diberikan kesimpulan valid karena nilai korelasi (pearson correlation) adalah positif dan $r$ Hitung lebih besar dari r Tabel. Namun terdapat 1 indikator yang tidak memenuhi persyaratan, maka 40 indikator yang telah dinyatakan valid.

\section{Tabel 4. Pengujian Validitas}

\section{Keseluruhan}

\begin{tabular}{|c|c|c|c|c|c|c|c|}
\hline No & Manifes & $\begin{array}{l}\text { Nilai } \\
\text { Output }\end{array}$ & Status & No & Manifes & $\begin{array}{l}\text { Nilai } \\
\text { Output }\end{array}$ & Status \\
\hline 1 & PU 1 & 0,477 & Valid & 26 & AC 5 & 0,755 & Valid \\
\hline 2 & PU 2 & 0,668 & Valid & 27 & FT 1 & 0,783 & Valid \\
\hline 3 & PU 3 & 0,849 & Valid & 28 & FT 2 & 0,888 & Valid \\
\hline 4 & PU 4 & 0,898 & Valid & 29 & FT 3 & 0,854 & Valid \\
\hline 5 & PU 5 & 0,697 & Valid & 30 & FT 4 & 0,851 & Valid \\
\hline 6 & PU 6 & 0,877 & Valid & 31 & FT 5 & 0,822 & Valid \\
\hline 7 & PEOU 1 & 0,193 & $\begin{array}{l}\text { Tidak } \\
\text { Valid }\end{array}$ & 32 & EU 1 & 0,894 & Valid \\
\hline 8 & PEOU 2 & 0,796 & Valid & 33 & EU 2 & 0,922 & Valid \\
\hline 9 & PEOU 3 & 0,813 & Valid & 34 & EU 3 & 0,799 & Valid \\
\hline 10 & PEOU 4 & 0,825 & Valid & 35 & EU 4 & 0,736 & Valid \\
\hline 11 & PEOU 5 & 0,721 & Valid & 36 & EU 5 & 0,745 & Valid \\
\hline 12 & PEOU 6 & 0,921 & Valid & 37 & TL 1 & 0,836 & Valid \\
\hline 13 & AT 1 & 0,753 & Valid & 38 & TL 2 & 0,860 & Valid \\
\hline 14 & AT 2 & 0,875 & Valid & 39 & TL 3 & 0,751 & Valid \\
\hline 15 & AT 3 & 0,839 & Valid & 40 & TL 4 & 0,868 & Valid \\
\hline 16 & AT 4 & 0,847 & Valid & 41 & TL 5 & 0,774 & Valid \\
\hline 17 & CT 1 & 0,894 & Valid & & & & \\
\hline 18 & CT 2 & 0,922 & Valid & & & & \\
\hline 19 & CT 3 & 0,799 & Valid & & & & \\
\hline 20 & CT 4 & 0,736 & Valid & & & & \\
\hline 21 & CT 5 & 0,745 & Valid & & & & \\
\hline 22 & $\mathrm{AC} 1$ & 0,737 & Valid & & & & \\
\hline 23 & $\mathrm{AC} 2$ & 0,823 & Valid & & & & \\
\hline 24 & AC 3 & 0,887 & Valid & & & & \\
\hline$\frac{24}{25}$ & AC 4 & 0,667 & Valid & & & & \\
\hline
\end{tabular}

\section{F. Uji Reliabilitas}

Reliabilitas menunjuk pada suatu pengertian bahwa sesuatu cukup dapat dipercaya untuk digunakan sebagai alat pengumpul data karena instrument tersebut sudah baik. Angket dikatakan reliabel jika dapat memberikan hasil relatif sama pada saat dilakukan pengukuran kembali pada obyek yang berlainan pada waktu yang berbeda atau memberikan hasil yang tetap. Suatu instrumen dapat dikatakan reliabel apabila memiliki nilai Cronbach Alpha lebih besar dari 0,600.

Case Processing Summary

\begin{tabular}{ll|l|l} 
& & $\mathrm{N}$ & $\%$ \\
\hline Cases & Valid $^{\mathrm{a}}$ & 30 & 100.0 \\
\cline { 2 - 4 } & Excluded $^{\mathrm{a}}$ & 0 & .0 \\
\cline { 2 - 4 } & Total & 30 & 100.0 \\
\hline
\end{tabular}

a. Listwise deletion based on all variables in the procedure.

\section{Reliability Statistics \\ Cronbach's}

\begin{tabular}{l|l} 
Alpha & $\mathrm{N}$ of Items \\
\hline .968 & 41 \\
\hline
\end{tabular}

\section{Gambar 4. Nilai Cronbach's Alpha Kuesioner}

Kuesioner dinyatakan reliabel apabila nilai Cronbach's Alpha yang didapat lebih besar dari 0,600, nilai Cronbach's Alpha yang didapat adalah 0,964 maka kuesioner ini dapat dinyatakan reliabel.

\section{G. Pengujian Ulang}

Setelah menghilangkan item - item yang tidak valid maka pengujian yang menghasilkan tabel validitas item kuesioner seperti pada tabel 6 . 
Tabel 5. Pengujian Ulang

\begin{tabular}{|c|c|c|c|c|}
\hline No & $\begin{array}{l}\text { Korelasi } \\
\text { item } \\
\text { dengan } \\
\text { total }\end{array}$ & $\begin{array}{l}\mathbf{r} \\
\text { Hitung }\end{array}$ & $\begin{array}{l}\text { r Tabel } \\
\text { df }=371 \alpha \\
=0.05\end{array}$ & $\begin{array}{l}\text { Kesimpul } \\
\text { an }\end{array}$ \\
\hline 1 & PU 1 & 0,237 & \multirow{40}{*}{0,113} & Valid \\
\hline 2 & PU 2 & 0,758 & & Valid \\
\hline 3 & PU 3 & 0,801 & & Valid \\
\hline 4 & PU 4 & 0,845 & & Valid \\
\hline 5 & PU 5 & 0,694 & & Valid \\
\hline 6 & PU 6 & 0,783 & & Valid \\
\hline 7 & PEOU 2 & 0,840 & & Valid \\
\hline 8 & $\begin{array}{l}\text { PEOU } 3 \\
\end{array}$ & 0,841 & & Valid \\
\hline 9 & PEOU 4 & 0,849 & & Valid \\
\hline 10 & PEOU 5 & 0,750 & & Valid \\
\hline 11 & PEOU 6 & 0,748 & & Valid \\
\hline 12 & AT 1 & 0,751 & & Valid \\
\hline 13 & AT 2 & 0,780 & & Valid \\
\hline 14 & AT 3 & 0,784 & & Valid \\
\hline 15 & AT 4 & 0,813 & & Valid \\
\hline 16 & CT 1 & 0,794 & & Valid \\
\hline 17 & CT 2 & 0,794 & & Valid \\
\hline 18 & CT 3 & 0,789 & & Valid \\
\hline 19 & CT 4 & 0,787 & & Valid \\
\hline 20 & CT 5 & 0,759 & & Valid \\
\hline 21 & AC 1 & 0,813 & & Valid \\
\hline 22 & AC 2 & 0,817 & & Valid \\
\hline 23 & AC 3 & 0,735 & & Valid \\
\hline 24 & $\mathrm{AC} 4$ & 0,647 & & Valid \\
\hline 25 & AC 5 & 0,781 & & Valid \\
\hline 26 & FT 1 & 0,826 & & Valid \\
\hline 27 & FT 2 & 0,847 & & Valid \\
\hline 28 & FT 3 & 0,791 & & Valid \\
\hline 29 & FT 4 & 0,759 & & Valid \\
\hline 30 & FT 5 & 0,810 & & Valid \\
\hline 31 & EU 1 & 0,699 & & Valid \\
\hline 32 & EU 2 & 0,877 & & Valid \\
\hline 33 & EU 3 & 0,826 & & Valid \\
\hline 34 & EU 4 & 0,848 & & Valid \\
\hline 35 & EU 5 & 0,797 & & Valid \\
\hline 36 & TL 1 & 0,806 & & Valid \\
\hline 37 & TL 2 & 0,833 & & Valid \\
\hline 38 & TL 3 & 0,822 & & Valid \\
\hline 39 & TL 4 & 0,868 & & Valid \\
\hline 40 & TL 5 & 0,820 & & Valid \\
\hline
\end{tabular}

Model pengujian validitas ini menggunakan rumus korelasi biverate pearson untuk menguji validitas internal setiap item pertanyaan dalam kuesioner. Hasil pengujian ulang dengan SPSS 26 menunjukkan bahwa semua item pertanyaan memiliki nilai $r$ Hitung lebih besar dari $r$ Tabel yang memiliki arti lebih besar dari 0,113. Maka dari itu dapat disimpulkan bahwa pada pengujian hasil ulang secara keseluruhan item dalam kuesioner adalah valid. Pengujian ini juga mengubah $\mathrm{N}$ reliabilitas kuesioner dari 0,968 menjadi 0,959 yang tetap masih diatas 0,600 sehingga masih dinyatakan reliabel.

\section{Case Processing Summary}

\begin{tabular}{ll|l|l} 
& & $\mathrm{N}$ & $\%$ \\
\hline \multirow{3}{*}{ Cases } & Valid $^{\mathrm{a}}$ & 373 & 100.0 \\
\cline { 2 - 4 } & Excluded $^{\mathrm{a}}$ & 0 & .0 \\
\cline { 2 - 4 } & Total & 373 & 100.0 \\
\hline
\end{tabular}

a. Listwise deletion based on all variables in the procedure.

\section{Reliability Statistics}

Cronbach's

\begin{tabular}{l|l} 
Alpha & $\mathrm{N}$ of Items \\
\hline .959 & 40 \\
\hline
\end{tabular}

\section{Gambar 5. Nilai Cronbach's Alpha Kuesioner Ulang}

\section{HASIL DAN PEMBAHASAN}

\section{A. Operasional Variabel}

Setelah melakukan uji validitas dan reliabilitas, diperoleh hasil bahwa model penelitian ini reliabel dan manifes penelitian. Gambar 9 merupakan model penelitian digambarkan menggunakan software AMOS 26.

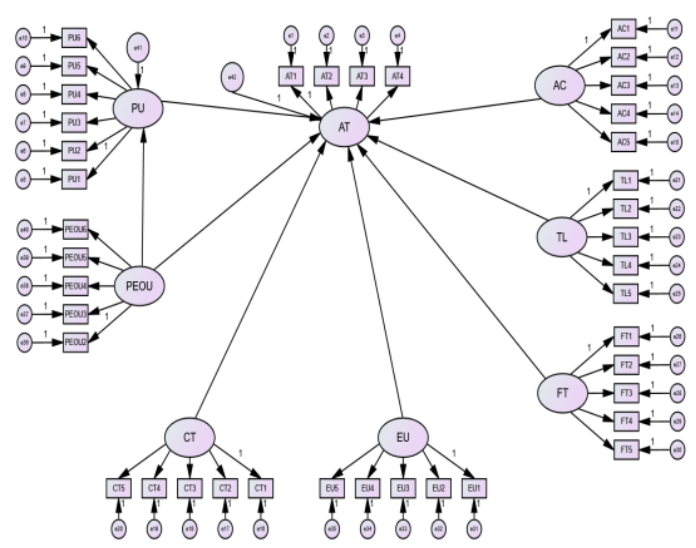

Gambar 6. Operasional Variabel 


\section{B. Pengujian Operasional Variabel 1. Pengujian Tahap Pertama}

Model penelitian ini terdiri atas sembilan konstruk dan empat puluh empat manifes, yaitu konstruk persepsi kegunaan dengan enam buah manifes, konstruk persepsi kemudahan penggunaan dengan lima buah manifes, konstruk sikap terhadap perilaku dengan empat buah manifes, konstruk isi dengan lima buah manifes, konstruk keakuratan dengan lima buah manifes, konstruk tampilan dengan lima buah manifes, konstruk kemudahan dengan lima buah manifes, konstruk ketepatan waktu dengan lima buah manifes dan konstruk persepsi keunggulan relatif dengan empat buah manifest. Pada tahap pertama, model yang dihipotesiskan menghasilkan parameter seperti digambarkan seperti berikut ini.

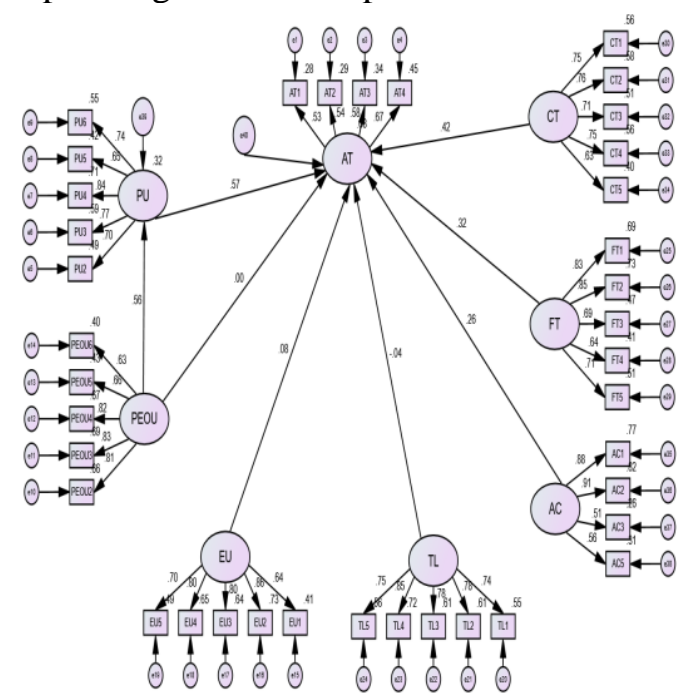

\section{Gambar 7. Hasil Pengujian Tahap Pertama}

2. Uji Validitas (Convergen Validity) Tahap Pertama

Uji Validitas (convergent validity) digunakan untuk menguji apakah sebuah indikator adalah bagian dari sebuah konstruk. Uji validitas bisa dilihat dari nilai standardized regression weight. Hasil uji convergent validity untuk penelitian ini ditampilkan sebagai berikut. Berdasarkan tabel 6 , seluruh indikator berhubungan dari konstruknya dan signifikan secara statistik. Sehingga seluruh indikator memang merupakan bagian dari konstruknya. Untuk melengkapi, berikut disertakan tampilan estimate yang sudah distandarisasi.
Tabel 6 Standardized regression weights Tahap Pertama

\begin{tabular}{|c|c|c|c|}
\hline & & & Estimate \\
\hline AT1 & $<--$ & AT & .529 \\
\hline AT2 & $<--$ & AT & .537 \\
\hline AT3 & $<--$ & AT & .580 \\
\hline AT4 & $<--$ & AT & .667 \\
\hline PU1 & $<--$ & PU & .034 \\
\hline PU2 & $<--$ & PU & .697 \\
\hline PU3 & $<--$ & PU & .765 \\
\hline PU4 & $<--$ & PU & .842 \\
\hline PU5 & $<--$ & PU & .645 \\
\hline PU6 & $<--$ & PU & .742 \\
\hline $\mathrm{AC} 1$ & $<--$ & $\mathrm{AC}$ & .884 \\
\hline $\mathrm{AC} 2$ & $<--$ & $\mathrm{AC}$ & .892 \\
\hline AC3 & $<--$ & $\mathrm{AC}$ & .522 \\
\hline $\mathrm{AC} 4$ & $<--$ & $\mathrm{AC}$ & .444 \\
\hline AC5 & $<--$ & $\mathrm{AC}$ & .587 \\
\hline CT1 & $<--$ & $\mathrm{CT}$ & .747 \\
\hline $\mathrm{CT} 2$ & $<---$ & $\mathrm{CT}$ & .762 \\
\hline CT3 & $<---$ & $\mathrm{CT}$ & .712 \\
\hline CT4 & $<--$ & $\mathrm{CT}$ & .750 \\
\hline CT5 & $<--$ & CT & .630 \\
\hline TL1 & $<--$ & TL & .742 \\
\hline TL2 & $<--$ & TL & .782 \\
\hline TL3 & $<--$ & TL & .784 \\
\hline TL4 & $<---$ & TL & .851 \\
\hline TL5 & $<--$ & TL & .750 \\
\hline FT1 & $<--$ & FT & .830 \\
\hline FT2 & $<---$ & FT & .853 \\
\hline FT3 & $<--$ & FT & .685 \\
\hline FT4 & $<--$ & FT & .638 \\
\hline FT5 & $<---$ & FT & .713 \\
\hline EU1 & $<--$ & EU & .638 \\
\hline EU2 & $<--$ & EU & .855 \\
\hline EU3 & $<--$ & EU & .800 \\
\hline EU4 & $<--$ & EU & .804 \\
\hline EU5 & $<---$ & EU & .698 \\
\hline PEOU2 & $<--$ & PEOU & .814 \\
\hline PEOU3 & $<---$ & PEOU & .829 \\
\hline PEOU4 & $<--$ & PEOU & .819 \\
\hline PEOU5 & $<--$ & PEOU & .655 \\
\hline PEOU6 & $<---$ & PEOU & .633 \\
\hline
\end{tabular}


Factor Loading yang bernilai > $>, 5$ menunjukkan bahwa sebuah indikator memang bagian dari konstruk (Santoso, 2014). Dari hasil tabel diatas, maka indikator yang mempunyai loading factor dibawah 0,5 berarti tidak valid, karena tidak sesuai syarat convergent validity. Sehingga indikator yang harus dibuang pada model adalah PU1 dan AC4.

\section{Uji Model Tahap Pertama}

Pengujian konstruk dan model penelitian dilakukan menggunakan SPSS AMOS 26. Gambar 8 merupakan model penelitian yang dibuat menggunakan AMOS. Gambar 8 merupakan hasil uji model tahap pertama setalah indikator dihilangkan.

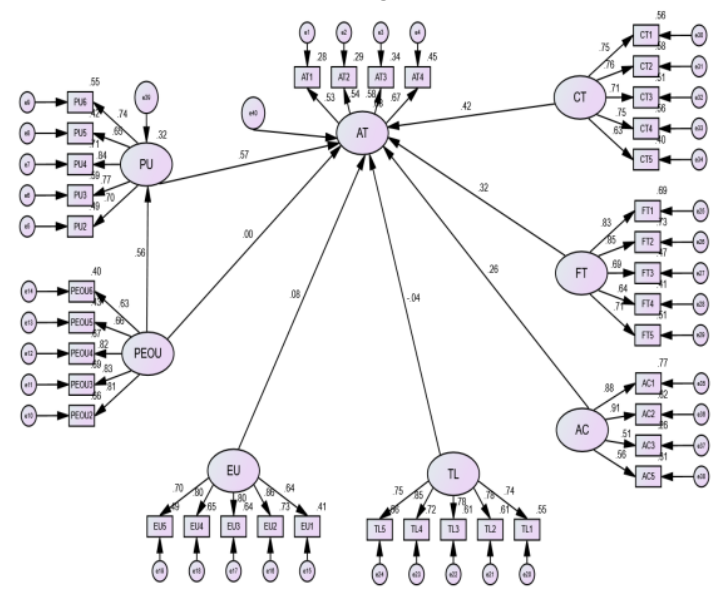

Gambar 8. Hasil Pengujian Tahap Pertama

Hasil pengujian model struktural menggunakan SPSS AMOS 26 menghasilkan tingkat kesesuaian seperti pada tabel 7.

Tabel 7 Hasil Uji Model Tahap Pertama

\begin{tabular}{|l|l|l|l|}
\hline $\begin{array}{l}\text { Kriteria Model } \\
\text { Fit }\end{array}$ & Hasil Uji & $\begin{array}{l}\text { Acceptable } \\
\text { Level }\end{array}$ & Interpretasi \\
\hline $\begin{array}{l}\text { CMIN (Chi } \\
\text { Square) }\end{array}$ & 3890.173 & $\begin{array}{l}\text { Diantara } \\
\text { Saturated dan } \\
\text { Independence } \\
\text { Model }\end{array}$ & $\begin{array}{l}\text { Kesesuaian } \\
\text { Baik }\end{array}$ \\
\hline $\begin{array}{l}\text { GFI (Goodness } \\
\text { of Fit Index) }\end{array}$ & 0.566 & $\begin{array}{l}0 \text { (tidak fit) } \\
\text { s/d 1 (Fit) }\end{array}$ & $\begin{array}{l}\text { Kesesuaian } \\
\text { Menengah }\end{array}$ \\
\hline $\begin{array}{l}\text { AGFI (Adjustes } \\
\text { GFI) }\end{array}$ & 0.511 & $\begin{array}{l}0 \text { (tidak fit) } \\
\text { s/d 1 (Fit) }\end{array}$ & $\begin{array}{l}\text { Kesesuaian } \\
\text { Menengah }\end{array}$ \\
\hline $\begin{array}{l}\text { RMSEA (Root } \\
\text { mean square } \\
\text { error } \\
\text { approximation) }\end{array}$ & 0.115 & $<0.080$ (Fit) & $\begin{array}{l}\text { Kesesuaian } \\
\text { Rendah }\end{array}$ \\
\hline $\begin{array}{l}\text { TLI (Tucker- } \\
\text { Lewis Index) }\end{array}$ & 0.641 & $\begin{array}{l}0 \text { (tidak fit) } \\
\text { s/d 1 (Fit) }\end{array}$ & $\begin{array}{l}\text { Kesesuaian } \\
\text { Menengah }\end{array}$ \\
\hline $\begin{array}{l}\text { NFI (Normed } \\
\text { Fit Index) }\end{array}$ & 0.623 & 0 (tidak fit) & $\begin{array}{l}\text { Kesesuaian } \\
\text { s/d 1 (Fit) }\end{array}$ \\
\hline $\begin{array}{l}\text { CFI fenengah } \\
\text { (Confirmatory } \\
\text { Fit Index) }\end{array}$ & 0.664 & $\begin{array}{l}0 \text { (tidak fit) } \\
\text { s/d 1 (Fit) }\end{array}$ & $\begin{array}{l}\text { Kesesuaian } \\
\text { Menengah }\end{array}$ \\
\hline $\begin{array}{l}\text { PNFI } \\
\text { Parcimonious } \\
\text { Fit Index) }\end{array}$ & 0.583 & $>0.600$ (Fit) & $\begin{array}{l}\text { Kesesuaian } \\
\text { Rendah }\end{array}$ \\
\hline
\end{tabular}

Dari tabel 7 dapat terlihat bahwa model tahap pertama memiliki kesesuaian menengah hanya nilai RMSEA yang tidak memenuhi kriteria.

\section{Pengujian Tahap Kedua}

Dari hasil pengujian tahap pertama tersebut, masih terdapat data-data yang mengandung outlier dalam mengukur konstruknya dan indikator PU1 dan AC4 sehingga mempengaruh goodness of fit dari model yang dihipotesiskan. Dalam tahap kedua ini, dilakukan pengulangan pengujian kembali setelah outlier dan indikator PU1 dan AC4 dihapus. Berikut hasil pengujian tahap kedua atau model setelah direvisi:

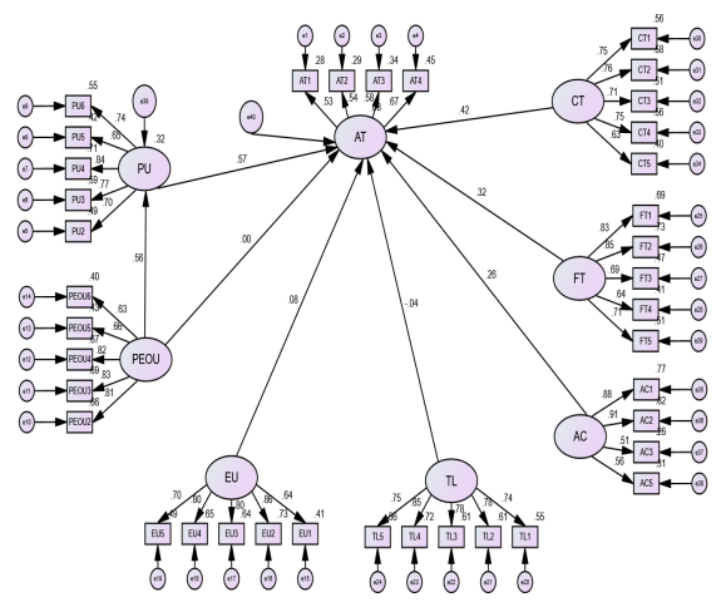

\section{Gambar 9. Model Pengujian Tahap Kedua}

\section{Uji Validitas (Convergen Validity) Tahap Kedua}

Berdasarkan tabel 8, seluruh indikator berhubungan dari konstruknya dan signifikan secara statistik. Sehingga seluruh indikator memang merupakan bagian dari konstruknya. Untuk melengkapi, berikut disertakan tampilan estimate yang sudah distandarisasi.

Tabel 8. Standardized regression weights Tahap Kedua

\begin{tabular}{|lll|l|}
\hline & & & Estimate \\
\hline AT1 & $<---$ & AT & .528 \\
AT2 & $<---$ & AT & .537 \\
AT3 & $<---$ & AT & .580 \\
AT4 & $<---$ & AT & .667 \\
PU2 & $<---$ & PU & .697 \\
PU3 & $<---$ & PU & .765 \\
PU4 & $<---$ & PU & .842 \\
PU5 & $<---$ & PU & .645 \\
PU6 & $<---$ & PU & .742 \\
PEOU2 & $<---$ & PEOU & .814 \\
PEOU3 & $<---$ & PEOU & .829 \\
PEOU4 & $<---$ & PEOU & .819 \\
PEOU5 & $<---$ & PEOU & .655 \\
PEOU6 & $<---$ & PEOU & .633 \\
\hline
\end{tabular}




\begin{tabular}{|lll|l|}
\hline & & & Estimate \\
\hline EU1 & $<---$ & EU & .638 \\
EU2 & $<---$ & EU & .855 \\
EU3 & $<---$ & EU & .801 \\
EU4 & $<---$ & EU & .804 \\
EU5 & $<---$ & EU & .698 \\
TL1 & $<---$ & TL & .742 \\
TL2 & $<---$ & TL & .782 \\
TL3 & $<---$ & TL & .784 \\
TL4 & $<---$ & TL & .851 \\
TL5 & $<---$ & TL & .750 \\
FT1 & $<---$ & FT & .830 \\
FT2 & $<---$ & FT & .853 \\
FT3 & $<---$ & FT & .685 \\
FT4 & $<---$ & FT & .639 \\
FT5 & $<---$ & FT & .713 \\
CT1 & $<---$ & CT & .747 \\
CT2 & $<---$ & CT & .762 \\
CT3 & $<---$ & CT & .712 \\
CT4 & $<---$ & CT & .750 \\
CT5 & $<---$ & CT & .630 \\
AC1 & $<---$ & AC & .880 \\
AC2 & $<---$ & AC & .907 \\
AC3 & $<---$ & AC & .514 \\
AC5 & $<---$ & AC & .561 \\
\hline
\end{tabular}

Factor Loading yang bernilai > 0,5 menunjukkan bahwa sebuah indikator memang bagian dari konstruk (Santoso, 2014). Dari hasil tabel diatas, maka indikator yang mempunyai loading factor dibawah 0,5 berarti tidak valid, karena tidak sesuai syarat convergent validity.

\section{Pengujian Hipotesis dengan SEM}

Pengujian hipotesis penelitian berdasarkan pada model penelitian yang dikembangkan, pengujian ini dilakukan untuk melihat hubungan diantara konstruk - konstruk yang ada dalam model penelitian. Daftar pengambilan keputusan diambil dengan melihat bobot regresi untuk konstruk terkait pada hasil pengujian menggunakan SPSS AMOS 26. Jika nilai $\mathrm{P}>0.05$ maka $\mathrm{H} 0$ ditolak dan apabila nilai $\mathrm{P}<0.05$ atau dilambangkan dengan $* * *$ maka $\mathrm{H} 1$ diterima seperti dipaparkan pada tabel 9.

Tabel 9. Hasil Nilai Regression Weights Model Penelitian

\begin{tabular}{|c|c|c|c|c|c|c|c|}
\hline & & & $\begin{array}{l}\text { Estima } \\
\text { te }\end{array}$ & $\begin{array}{l}\text { S.E } \\
\text {. }\end{array}$ & C.R. & $\mathbf{P}$ & Label \\
\hline PU & $\begin{array}{l}<-- \\
-\end{array}$ & $\begin{array}{l}\text { PEO } \\
\mathrm{U}\end{array}$ & .522 & $\begin{array}{l}.05 \\
9\end{array}$ & $\begin{array}{l}8.91 \\
1\end{array}$ & $* * *$ & $\begin{array}{l}\text { par_3 } \\
3\end{array}$ \\
\hline $\begin{array}{l}\mathrm{A} \\
\mathrm{T}\end{array}$ & $\begin{array}{l}<- \\
-\end{array}$ & PU & .347 & $\begin{array}{l}.05 \\
6\end{array}$ & $\begin{array}{l}6.19 \\
8\end{array}$ & $* * *$ & $\begin{array}{l}\text { par_3 } \\
1\end{array}$ \\
\hline $\begin{array}{l}\mathrm{A} \\
\mathrm{T}\end{array}$ & $\begin{array}{l}<-- \\
-\end{array}$ & $\begin{array}{l}\text { PEO } \\
\mathrm{U}\end{array}$ & .001 & $\begin{array}{l}.04 \\
4\end{array}$ & .025 & $\begin{array}{l}.98 \\
0\end{array}$ & $\begin{array}{l}\text { par_3 } \\
2\end{array}$ \\
\hline $\begin{array}{l}\mathrm{A} \\
\mathrm{T}\end{array}$ & $\begin{array}{l}<- \\
-\end{array}$ & EU & .057 & $\begin{array}{l}.07 \\
1\end{array}$ & .806 & $\begin{array}{l}.42 \\
0\end{array}$ & $\begin{array}{l}\text { par_3 } \\
4\end{array}$ \\
\hline A & $<-$ & TL & -.025 & .05 & - & .66 & par_3 \\
\hline
\end{tabular}

\begin{tabular}{|c|c|c|c|c|c|c|c|}
\hline & & & $\begin{array}{l}\text { Estima } \\
\text { te }\end{array}$ & $\begin{array}{l}\text { S.E } \\
\text {. }\end{array}$ & C.R. & $\mathbf{P}$ & Label \\
\hline $\mathrm{T}$ & - & & & 7 & .438 & 1 & 5 \\
\hline $\begin{array}{l}\mathrm{A} \\
\mathrm{T}\end{array}$ & $\begin{array}{l}<- \\
-\end{array}$ & $\mathrm{AC}$ & .128 & $\begin{array}{l}.03 \\
9\end{array}$ & $\begin{array}{l}3.26 \\
2\end{array}$ & $\begin{array}{l}.00 \\
1\end{array}$ & $\begin{array}{l}\text { par_3 } \\
6\end{array}$ \\
\hline $\begin{array}{l}\mathrm{A} \\
\mathrm{T}\end{array}$ & $\begin{array}{l}<- \\
-\end{array}$ & FT & .169 & $\begin{array}{l}.05 \\
1\end{array}$ & $\begin{array}{l}3.30 \\
1\end{array}$ & $* * *$ & $\begin{array}{l}\text { par_3 } \\
7\end{array}$ \\
\hline $\begin{array}{l}\mathrm{A} \\
\mathrm{T}\end{array}$ & $\begin{array}{l}<-- \\
-\end{array}$ & $\mathrm{CT}$ & .259 & $\begin{array}{l}.06 \\
0\end{array}$ & $\begin{array}{l}4.30 \\
9\end{array}$ & $* * *$ & $\begin{array}{l}\text { par_3 } \\
8\end{array}$ \\
\hline
\end{tabular}

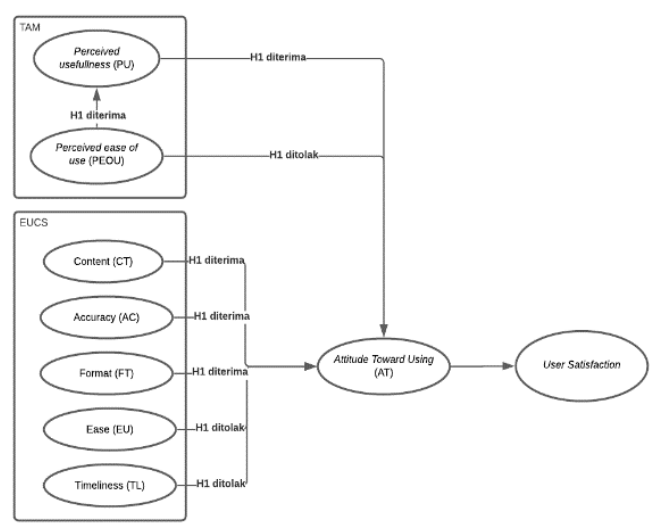

Gambar 10. Model Hipotesis Penelitian Akhir

Berdasarkan pada hasil analisa pada gambar 10 dengan menghilangkan hipotesa yang ditolak maka dibentuklah model struktural yang baru dimana konstruk PEOU, TL dan EU setelah dihapus dengan hubungan AT, seperti dapat dilihat pada gambar 11 .

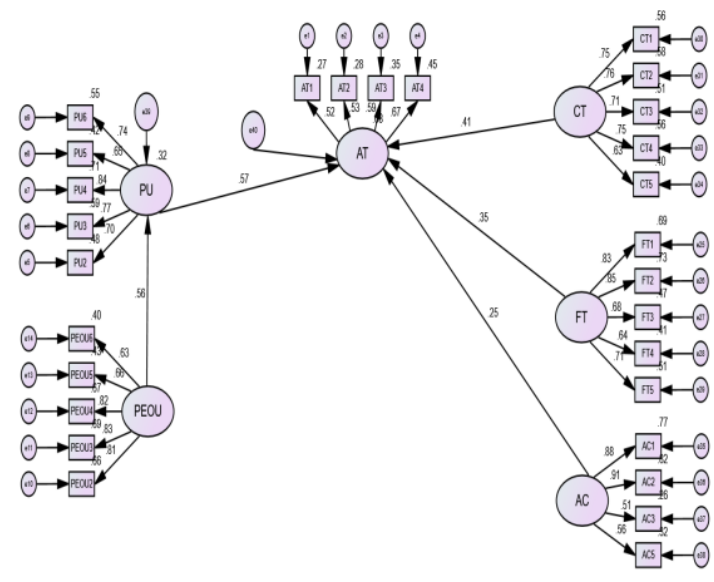

\section{Gambar 11. Model Penelitian Struktural Hipotesis Akhir}

Model penelitian struktural tahap pertama kemudian dilakukan pengujian ulang untuk mengetahui tingkat kesesuaiannya, hasil pengujian model struktural menggunakan SPSS AMOS 26 menghasilkan tingkat kesesuaian. 
Pengujian ulang hipotesis penelitian berdasarkan pada model penelitian yang telah diulang, pengujian ini dilakukan untuk melihat hubungan diantara konstruk - konstruk yang ada dalam model penelitian. Dasar pengambilan keputusan diambil dengan melihat bobot regresi untuk konstruk terkait pada hasil pengujian menggunakan SPSS AMOS 26. Jika $\mathrm{p}>0.05$ maka H0 ditolak dan apabila $\mathrm{p}<0.05$ atau dilambangkan dengan *** maka $\mathrm{H} 1$ diterima seperti dipaparkan pada tabel 10.

Tabel 10. Hasil Nilai Regression Weights Model Penelitian Hipotesis Akhir

\begin{tabular}{|c|c|c|c|c|c|c|c|}
\hline & & & $\begin{array}{l}\text { Estimat } \\
\mathrm{e}\end{array}$ & $\begin{array}{l}\text { S.E } \\
\text {. }\end{array}$ & C.R. & $\mathrm{P}$ & Label \\
\hline PU & $\begin{array}{l}<- \\
-\end{array}$ & $\begin{array}{l}\text { PEO } \\
\mathrm{U}\end{array}$ & .522 & $\begin{array}{l}.05 \\
9\end{array}$ & $\begin{array}{l}8.92 \\
5\end{array}$ & $* * *$ & $\begin{array}{l}\text { par_2 } \\
4\end{array}$ \\
\hline $\begin{array}{l}\mathrm{A} \\
\mathrm{T}\end{array}$ & $\begin{array}{l}<-- \\
-\end{array}$ & PU & .344 & $\begin{array}{l}.05 \\
1\end{array}$ & $\begin{array}{l}6.67 \\
7\end{array}$ & $* * *$ & $\begin{array}{l}\text { par_2 } \\
3\end{array}$ \\
\hline $\begin{array}{l}\mathrm{A} \\
\mathrm{T}\end{array}$ & $\begin{array}{l}<- \\
-\end{array}$ & $\mathrm{AC}$ & .119 & $\begin{array}{l}.03 \\
7\end{array}$ & $\begin{array}{l}3.21 \\
9\end{array}$ & $\begin{array}{l}.00 \\
1\end{array}$ & $\begin{array}{l}\text { par_2 } \\
5\end{array}$ \\
\hline $\begin{array}{l}\mathrm{A} \\
\mathrm{T}\end{array}$ & $\begin{array}{l}<- \\
-\end{array}$ & FT & .184 & $\begin{array}{l}.04 \\
2\end{array}$ & $\begin{array}{l}4.35 \\
5\end{array}$ & $* * *$ & $\begin{array}{l}\text { par_2 } \\
6\end{array}$ \\
\hline $\begin{array}{l}\mathrm{A} \\
\mathrm{T}\end{array}$ & $\begin{array}{l}<- \\
-\end{array}$ & CT & .254 & $\begin{array}{l}.05 \\
7\end{array}$ & $\begin{array}{l}4.46 \\
5\end{array}$ & $* * *$ & $\begin{array}{l}\text { par_2 } \\
7\end{array}$ \\
\hline
\end{tabular}

\section{Analisis Pengaruh Total}

Pada model yang telah ditrimming terdapat tujuh variabel yang terdiri dari dua variabel eksogen (PU, AT) dan lima variabel endogen (PEOU, AC, CT, FT). Berikut pengaruh masing - masing variabel ;

1. Konstruk PEOU terhadap konstruk PU Perceived Ease of Use (PEOU) terhadap memberi pengaruh positif sebesar 52,2\% terhadap Perceived Usefullness (PU).

2. Konstruk PU terhadap konstruk AT Perceived Usefullness (PU) terhadap memberi pengaruh positif sebesar 34,4\% terhadap Attitude Toward Using (AT).

3. Konstruk CT terhadap konstruk AT Content (CT) terhadap memberi pengaruh positif sebesar 25,4\% terhadap Attitude Toward Using (AT).

4. Konstruk AC terhadap konstruk AT Accuracy (AC) terhadap memberi pengaruh positif sebesar $11,9 \%$ terhadap Attitude Toward Using (AT).

5. Konstruk FT terhadap konstruk AT Format (FT) terhadap memberi pengaruh positif sebesar 18,4\% terhadap Attitude Toward Using (AT).

\section{KESIMPULAN}

Berdasarkan hasil pengolahan dan analisis yang dilakukan dapat disimpulkan bahwa dari 8 hipotesis yang diajukan ada beberapa hipotesis yang diterima dan ada yang ditolak. Sesuai dengan rumusan permasalahan yang telah diuraikan di awal terjawab bahwa hasil dari analisis dengan menggunakan metode TAM dan EUCS menunjukan a.) persepsi kemudahan penggunaan (PEOU) memberi pengaruh positif sebesar 52,2\% terhadap persepsi kegunaan (PU), b.) persepsi kegunaan (PU) memberi pengaruh positif sebesar $34,4 \%$ terhadap sikap (AT), c.) isi (CT) memberi pengaruh positif sebesar $25,4 \%$ terhadap sikap (AT), d.) keakuratan (AC) memberi pengaruh positif sebesar $11,9 \%$ terhadap sikap (AT), e.) tampilan (FT) memberi pengaruh positif sebesar $18,4 \%$ terhadap sikap (AT), sehingga bisa disimpulkan bahwa 5 hipotesis tersebut memiliki berpengaruh terhadap kepuasan mahasiswa dalam menggunakan Google Classroom.

\section{REFERENSI}

[1] L. Sofyana and A. Rozaq, "Pgri Madiun," Pembelajaran Daring Komb. Berbas. Whatsapp Pada Kelas Karyawan Prodi Tek. Inform. Univ. Pgri Madiun, vol. 8, pp. 81-86, 2019.

[2] A. B. Hakim, "Efektifitas Penggunaan E-Learning Moodle , Google Classroom Dan Edmodo," vol. 2, pp. 16, 2016.

[3] E. Yulianingsih, "E-Learning Menggunakan Technology Acceptance Model Dan End User Computing Satisfaction," J. Ilm. MATRIK, vol. 18, no. 1, pp. 27-42, 2016.

[4] K. N. M. N. Masitah and I. Ilhamsyah, "Evaluasi Kepuasan Pengguna Siakad Universitas Tanjungpura Menggunakan Integrasi Technology Acceptance Model (Tam) Dan End-User Computing Satisfaction (Eucs)," Coding J. Komput. dan Apl., vol. 8, no. 2, pp. 11-21, 2020, doi: 10.26418/coding.v8i2.41217.

[5] A. E. Hadisuwarno and R. Bisma, "Analisis penerimaan pengguna aplikasi e-Kinerja dengan metode TRAM dan EUCS pada kepolisian Analysis of user acceptance of e- 
Kinerja applications with the TRAM and EUCS methods at the police," $J$. Ilm. Sist. Inf., vol. 10, no. 2, pp. 93109, 2021.

[6] Abdul Haris Indrakusuma and A. R. Putri, E-Learning -Teori dan Desain. Tulungngagung: STKIP PGRI, 2016.

[7] B. Lee, "Blended Learning through Google Classroom," Int. J. Educ. Pedagog. Sci., vol. 14, no. 4, pp. 220226, 2020.

[8] Sugiyono, Metode Penelitian Kombinasi. Bandung: Alfabeta, 2016.

[9] C. S. P.L, Analisis Penerimaan Pengguna Akhir Dengan Menggunakan Technology Acceptance Model Dan End User Computing Satisfaction Terhadap Penerapan Sistem Core Banking Pada Bank Abc Tesis. 2006.

[10] S. Santoso, Panduan Lengkap SPSS 26. Jakarta: Elex Media Komputindo, 2020.

[11] S. Santoso, Analisis SEM menggunakan AMOS. Jakarta: Elex Media Komputindo, 2014.

[12] A. P. Sari and M. A. Syamsuddin, "Analisis Faktor End-User Computing Satisfaction Terhadap Kepuasan Pengguna: Studi Kasus Kantor Pelayanan Pajak Madya Balikpapan," J. Pajak Indones., vol. 1, no. 2, pp. 92101, 2017.

[13] T. Loanata and K. G. Tileng, "Pengaruh Trust dan Perceived Risk pada Intention To Use Menggunakan Technology Acceptance Model (Studi Kasus Pada Situs E-Commerce Traveloka)," JUISI J. Inform. dan Sist. Inf., vol. 02, no. 2460-1306, p. 10, 2016.

[14] T. Farahat, "Applying the Technology Acceptance Model to Online Learning in the Egyptian Universities," Procedia - Soc. Behav. Sci., vol. 64, pp. 95-104, 2012, doi: 10.1016/j.sbspro.2012.11.012.

[15] Budiman, "Pengaruh Pemanfaatan Sistem Akademik Online Terhadap Kepuasan Mahasiswa Menggunakan Technology Acceptance Model (TAM)," Maj. Bisnis Dan IPTEK, vol. 9, no. 2, 2016, [Online]. Available: https://jurnal.stiepas.ac.id/index.php/bis tek/article/view/77.
[16] Z. Niqotaini, "Analisis Penerimaan Dan Penggunaan Media Pembelajaran Augmented Reality Dengan Menggunakan Model UTAUT-2 (Studi Kasus : SMP dan SMA Mutiara Bunda Bandung)," Technol. J. Ilm., vol. 12, no. 1, p. 4, 2021, doi: 10.31602/tji.v12i1.4175. 
Technologia"Vol 12, No. 4, Oktober-Desember 2021 